\title{
A survey of mobility behaviour as an example of research into the demand for urban transport in some Polish cities
}

\author{
K. Hebel \\ Faculty of Economics, Chair of Transportation Market, \\ University of Gdansk, Poland
}

\begin{abstract}
The scope of research into the demand for urban transport includes a survey of mobility behaviour. Its value is that it refers to both, the effective and the potential demand. This is why mobility behaviour is surveyed in public transport vehicles, at stops and stations, in selected sites in the city (during a comprehensive traffic study) and at the respondent's home.

Following the mobility behaviour survey, it is possible to define the modal split, the urban mobility of inhabitants and the destinations of their journeys, as well as the reasons why they choose public transport or the car for urban trips.

The article presents the results of mobility behaviour surveys concerning the effective demand in some of Polish towns and cities between 2000 and 2008, and mobility behaviour surveys of the inhabitants of Warsaw and Gdynia, covering also the possible demand.
\end{abstract}

Keywords: urban transport, mobility survey, mobility behaviour.

\section{Introduction}

The demand for public transport services in Polish cities has been shrinking since the late 1980s. This trend seems likely to continue, with the exception of the demand for the underground in Warsaw and the urban rail (SKM) in GdańskSopot-Gdynia (Tri-city). At the same time a rise is forecast in the role of the car in urban transport. Car share in urban transport is expected to grow from $56 \%$ to $70 \%$ between 2003 and 2020 [2].

As the demand for public transport services declines, the significance of research into the demand for urban transport grows. When the demand and its 
features are known, the public transport services provided can be better matched to the needs of the passengers, which should cause the demand to grow or at least stabilise at the present level.

\section{Demand for urban transport - the scope of the research}

In terms of content, research into the demand for urban transport can cover [3]:

- capacity and the way it is used;

- passenger structure;

- the extent to which season tickets are used;

- revenue levels of individual services;

- overall mobility demand;

- trip matrix;

- level of comfort;

- passenger preferences;

- mobility behaviour of urban population;

- attitudes of urban population to transport policies in cities.

Most of the research concerns effective demand for urban transport, whereas account must be taken of possible demand in the study of the overall mobility demand, mobility behaviour and preferences of urban population and of attitudes of the inhabitants to specific transport policies.

Effective demand is the total of trips made by public transport, while in addition to it, possible demand involves some of the trips made by car or other personal means of transport as well the needs which, for whatever reason, do not surface in the marketplace [4].

Mobility behaviour may be defined as the aggregate of measures and activities aimed at satisfying one's mobility needs by obtaining goods and services, in accordance with the individual's system of preferences. The effect of this process is specific mobility behaviour - going on foot, using urban transport or the car, or abandoning the trip altogether [5]. This is why it is so important that mobility behaviour of car users and those who have given up travelling is also surveyed.

The following are identified through mobility behaviour surveys: origin and destination of trips at specific periods during the day, modal split, mobility ratio, reasons for travelling and for choosing public transport or the car in urban transport.

Ideally, surveys should be conducted on a regular basis, as this makes it possible to adjust the services provided to changing mobility behaviour of the inhabitants.

\section{Methodology of mobility behaviour surveys}

Surveys of mobility behaviour connected with effective demand should be regular, i.e. they should be conducted twice a year. Each time they should cover a weekday, a Saturday and a Sunday, as particular times of the year and days of 
the week have their own characteristics. The survey should be comprehensive, i.e. cover all mobility tasks for a representative weekday, Saturday and Sunday. Tuesday, Wednesday and Thursday are considered to be representative weekdays.

The most appropriate periods for the market survey in urban transport, ensuring representative results, are the months of March and April in Spring and October and November in Autumn.

The methods and measurements used in the study of effective demand are observation and recording.

The observer may be inside or outside the vehicle. The observation conducted may be overt and should be standardised. For the results to be standardised, they should be recorded on specially designed charts [6].

Surveys of possible demand should be conducted in the respondent's home, so that both public transport and car users are included. It is also important, that residents of various districts are targeted, owing to which the trip matrix can be developed. Surveys at the respondent's home are costly and time-consuming, so they should be conducted at 2-4 years' intervals. They are done in the form of an interview, during which a survey questionnaire is used, to obtain standardised responses.

Some big cities run comprehensive traffic studies, occasionally or at 5-10 years' intervals. Such studies also include mobility behaviour surveys. Scorekeepers at selected posts count the passing cars and the people inside, as well as passengers of public transport vehicles. Surveyors, on the other hand, stop selected vehicles (e.g. every tenth vehicle), reaching both public transport passengers as well car drivers and passengers [7].

\section{Mobility behaviour - the findings of surveys at public transport stops and stations and in vehicles}

\subsection{Effective demand pattern}

Urban transport research in most Polish cities is limited to studying the volume of the demand. Only in some cities is the number of passengers examined broken down to weekdays, Saturdays and Sundays

Table 1 shows passenger numbers in some of Polish towns and cities on Saturday and Sunday, expressed as a percentage of weekday figure, established in the surveys conducted between 2002 and 2008 [8].

The findings of the survey confirm that the demand for public transport on Saturday is at ca. $50 \%$ of a weekday level, and on Sunday stands at 30 per cent.

The demand also fluctuates during the day. In a survey conducted by another research team in 14 Polish towns and 10 cities, between 1995 and 2004, these fluctuations were identified.

Morning mobility peak in all the towns and cities occurs between 7 and 8, and is felt particularly strongly in small towns. The afternoon peak in small and medium-sized towns lasts one or two hours, always beginning at 2 p.m. In cities, the afternoon peak continues for up to 3 hours [9]. 
Table 1: Saturday and Sunday passenger numbers as a percentage of weekday figure in some of Polish towns and cities in 2002-2008.

\begin{tabular}{|l|c|c|c|}
\hline City & Year of survey & Saturday (\%) & Sunday (\%) \\
\hline Słupsk & 2002 & 48.0 & 27.2 \\
\hline Malbork & 2002 & 47.6 & 36.1 \\
\hline Gorzów Wielkopolski & 2003 & 61.0 & 42.3 \\
\hline Starogard Gdański & 2003 & 54.0 & 37.6 \\
\hline Słupsk & 2004 & 53.8 & 30.0 \\
\hline Piotrków Trybunalski & 2004 & 46.8 & 37.6 \\
\hline Zamość & 2004 & 38.6 & 28.8 \\
\hline Olsztyn & 2004 & 55.0 & 34.3 \\
\hline Piła & 2005 & 51.1 & 29.8 \\
\hline Słupsk & 2006 & 52.1 & 29.3 \\
\hline Świdnica & 2006 & 42.2 & 31.9 \\
\hline Grudziądz & 2007 & 54.2 & 37.1 \\
\hline Koszalin & 2007 & 49.7 & 34.0 \\
\hline Zielona Góra & 2008 & 50.6 & 36.5 \\
\hline
\end{tabular}

Table 2: Mobility of season-ticket holders in selected Polish towns and cities between 2002-2008.

\begin{tabular}{|c|c|c|c|c|c|}
\hline \multirow{2}{*}{ City/town } & \multirow{2}{*}{$\begin{array}{l}\text { Year of } \\
\text { survey }\end{array}$} & \multicolumn{4}{|c|}{ Mobility (daily trip average ) } \\
\hline & & Weekday & Saturday & Sunday & Average \\
\hline \multicolumn{6}{|c|}{ Big cities } \\
\hline \multirow{2}{*}{ Cracow } & 2003 & 3.62 & 3.19 & 2.95 & 3.44 \\
\hline & 2004 & 3.71 & 3.71 & 3.33 & 3.65 \\
\hline \multirow{3}{*}{ Łódź } & 2002 & 3.15 & 2.5 & 1.98 & 2.86 \\
\hline & 2003 & 3.27 & 3.11 & 2.75 & 3.16 \\
\hline & 2004 & 3.21 & 3.11 & 2.73 & 3.12 \\
\hline \multicolumn{6}{|c|}{ Smaller cities } \\
\hline \multirow{2}{*}{ Gdynia } & 2004 & 2.78 & 2.39 & 1.88 & 2.58 \\
\hline & 2006 & 2.82 & 2.42 & 1.94 & 2.62 \\
\hline \multirow{2}{*}{ Słupsk } & 2002 & 2.88 & 2.02 & 0.92 & 2.44 \\
\hline & 2004 & 2.94 & 2.08 & 1.12 & 2.52 \\
\hline Gniezno & 2005 & 2.59 & 2.39 & 2.48 & 2.56 \\
\hline \multicolumn{6}{|c|}{ Towns } \\
\hline \multirow{5}{*}{ Rumia } & 2002 & 2.49 & 1.84 & 1.45 & 2.23 \\
\hline & 2003 & 2.19 & 1.65 & 1.53 & 2.01 \\
\hline & 2004 & 2.69 & 2.07 & 1.65 & 2.43 \\
\hline & 2005 & 2.27 & 2.03 & 1.5 & 2.11 \\
\hline & 2008 & 2.17 & 1.96 & 1.44 & 2.02 \\
\hline \multirow{5}{*}{ Sopot } & 2002 & 2.12 & 1.64 & 1.22 & 1.91 \\
\hline & 2003 & 2.05 & 1.72 & 1.45 & 1.91 \\
\hline & 2004 & 2.11 & 1.61 & 1.48 & 1.94 \\
\hline & 2005 & 2.08 & 1.81 & 1.81 & 2.00 \\
\hline & 2008 & 1.87 & 1.41 & 1.31 & 1.72 \\
\hline $\begin{array}{l}\text { Ostrów } \\
\text { Wielkopolski }\end{array}$ & 2003 & 2.27 & 2.87 & 2.53 & 2.40 \\
\hline
\end{tabular}




\subsection{Mobility level}

The results of mobility surveys of urban population allow us to establish the mobility ratio, which is the average daily number of trips per inhabitant (accounting for public versus personal transport modes) [10]. During the study of effective demand, the average mobility of regular public transport users, i.e. the people with season tickets, is determined.

Average mobility of season-ticket holders in selected Polish towns and cities, studied independently by two research teams [11] and [12] between 2002 and 2008, ranged from 1.31 to 3.65 and was definitely higher on weekdays (see Table 2). The mobility correlated with the size of the town/city, being the highest in cities and the lowest in small towns.

\section{Mobility behaviour identified during traffic studies in Warsaw urban area [13]}

\subsection{Methodology of the survey}

The mobility survey of inhabitants of the Warsaw urban area was conducted in 2005 with the use of a questionnaire, as an element of a traffic study. Its strength lies in that apart from trips made by public transport, it accounts for trips made by car or on foot.

\subsection{Forms of urban mobility}

Inhabitants of Warsaw and its suburbs make every fifth trip on foot. The youngest and the oldest are the most frequent walkers (in the 6-15 age group nearly $60 \%$ of the trips are made on foot, and in the $60+$ group -26.5 per cent). People between the ages of 16 and 60 make only $15 \%$ of their trips on foot.

Of all the other trips, $30 \%$ are made by car, and $61.8 \%$ by public transport (by bus $-35.5 \%$, by tram $-14.3 \%$, by bus and by tram $-8.6 \%$, by underground $3.4 \%)$.

In households with one car, $45 \%$ of the trips are made by public transport.

The most frequent public transport users are undergraduates - more than $77 \%$ of the trips, wage-earners $-56 \%$ and the unemployed - nearly $55 \%$; the least frequent are entrepreneurs - only $17.4 \%$.

\subsection{Destinations}

When people walk, they most typically go home (47.8\%), go shopping (20.8\%), go to school (13.3\%), go to work (5.6\%), accompany another person $(3.8) \%$ ).

Other destinations (hypermarket, college/university, entertainment, meeting friends or family, on business) account for only $2 \%$ of trips made on foot.

Destinations of longer trips which are not made on foot are: home (45.6\%), work (23.0\%), shopping and services (7.9\%), school (4.2\%).

Hypermarket and visiting friends or relations are a destination twice as often as when walking, and college/university - five times as often. 
Work is a destination more often for men (21.8\% of non-walking trips) than for women $(17.5 \%)$; the same applies to school $(6.7 \%$ versus $5.6 \%)$ and on business. Women's destinations are more often shopping, visiting friends or relations and college/university.

When it comes to occupational criteria, $80 \%$ of non-walking trips of junior students are made between school and home, 64\% of trips of undergraduates between home and university, $81.5 \%$ of wage-earners' - between home and work, and $72 \%$ of business people's - between home and work. The surveyed OAPs most often went home $(47.2 \%)$, shopping or to get a service $(27 \%)$, while the unemployed - home (45\%), shopping or to visit friends or relations $(15.6 \%$ and $10 \%$ respectively).

\subsection{Trip duration}

Average trip duration, whatever the destination, has become 4 minutes longer since 1993.

Suburban Warsaw residents spend, on the average, 64 minutes going home, 34 minutes going to work and 68 minutes going to a hypermarket.

Inner Warsaw residents spend, on the average, 39 minutes going home, 38 minutes going to work, 25 minutes going to school, 39 minutes going to college/university, 28 minutes going to the shops, 30 minutes going to a hypermarket, 36 minutes seeking leisure activities. 35 minutes travelling on business, 31 minutes going on a visit.

While travelling in Warsaw, its inhabitants seldom have to change. Nearly $50 \%$ are point-to-point trips, only 10 per cent of residents have to change two or more times. Suburban Warsaw residents most often have to change once (41\%), but $25 \%$ have to change twice or more.

\section{Mobility behaviour survey in Gdynia conducted at the respondent's home [14]}

\subsection{Methodology of the survey}

A survey of mobility behaviour at the respondent's home is conducted in Gdynia every two years by the University of Gdańsk and the Public Transport Authority (ZKM) in Gdynia.

The method of the survey is a standardised interview conducted at the respondent's home.

Sample size is always 1 per cent of the population of Gdynia, between the ages of 16 and 75 .

To make sure the sample is fully representative, stratified sampling is applied. This means the population is divided into groups according to their age, gender and the city district inhabited. Simple random sampling is then done within the groups. 


\subsection{Structure of the population}

The make-up of the population in Gdynia did not change significantly in the 2000-2008 period.

Age distribution is even, there is however a slight increase in the proportion of senior citizens.

The largest segment is composed of people in employment, although their share has been declining since 2000. When we look at the economic and financial efficiency of the urban transport, we must note the growing proportion of seniors in the population.

The proportion of people from households with a car has been growing, too, reaching $64.09 \%$ in 2008 .

\subsection{Forms of urban mobility}

Survey results indicate that the declared share of trips made by public transport has decreased (Table 3).

Table 3: The declared way of making urban trips [\% of population].

\begin{tabular}{|l|c|c|c|c|c|}
\hline \multicolumn{2}{|l|}{$\begin{array}{l}\text { Way of making urban } \\
\text { trips }\end{array}$} & \multicolumn{5}{|c|}{ Years } \\
\cline { 2 - 6 } & 2000 & 2002 & 2004 & 2006 & 2008 \\
\hline $\begin{array}{l}\text { Always by public } \\
\text { transport }\end{array}$ & 34.48 & 28.59 & 34.23 & 28.7 & $\begin{array}{c}27.6 \\
2\end{array}$ \\
\hline $\begin{array}{l}\text { Usually by public } \\
\text { transport }\end{array}$ & 27.29 & 30.07 & 27.59 & 26.5 & $\begin{array}{c}25.6 \\
7\end{array}$ \\
\hline $\begin{array}{l}\text { By public transport or } \\
\text { by car-equally often }\end{array}$ & 12.54 & 12.21 & 13.74 & 11.0 & $\begin{array}{c}11.0 \\
6\end{array}$ \\
\hline Usually by car & 13.79 & 15.01 & 12.07 & 16.0 & $\begin{array}{c}16.3 \\
1\end{array}$ \\
\hline Always by car & 10.96 & 13.42 & 10.19 & 17.6 & 18.9 \\
\hline Other ways & 0.91 & 0.70 & 2.18 & 0.2 & 0.41 \\
\hline
\end{tabular}

The share of trips always or usually made by public transport has gone down from $62 \%$ to $53 \%$. At the same time, the proportion of trips always or usually made by car has gone up from $24 \%$ to $35 \%$.

The declared way of making urban trips is determined on the basis of replies to the question: "How do you make urban trips?"

\subsection{Modal split}

On the basis of the so-called "image of yesterday" modal split for the day before the survey is determined.

Modal split determined upon the surveys from the 2000-2008 period is presented in fig. 1. Significant fluctuations can be observed, with an upward trend for car use. 
This can be attributed to the fact, that in the years 2000 and 2004 major reconstruction and upgrade of roads and junctions took place. The resulting traffic disruptions made some inhabitants temporarily give up the car, especially when going to work.

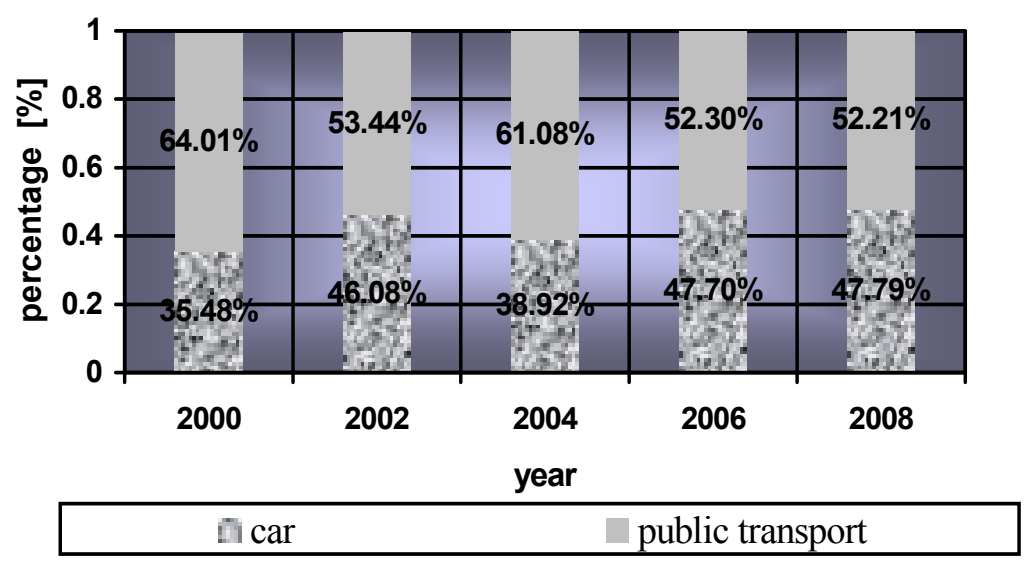

Figure 1: $\quad$ Modal split in Gdynia in 2000-2008.

\subsection{Urban mobility}

Urban mobility pattern is determined on the basis of the trips made the day preceding the survey, by whichever mode (including the car).

The traffic disruptions of 2000 and 2004 caused by major redevelopment and upgrade of city roads and streets are also reflected here. Urban mobility ratio for those years fell in Gdynia to 1.76 and 1.78 trips per day per inhabitant, respectively. The low mobility level for 2008 (1.64) can be attributed to bad weather at the time of the survey, inducing people to give up optional trips.

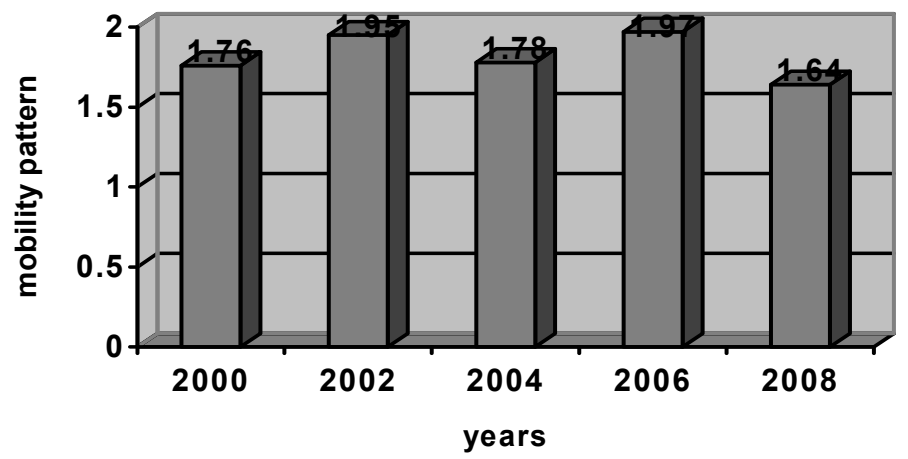

Figure 2: Mobility pattern of the inhabitants of Gdynia in 2000-2008. 
There is clear differentiation of the ratio between those who have a car and those who do not.

Changes in mobility ratio of main car users and persons from no-car households are shown in fig. 3 .
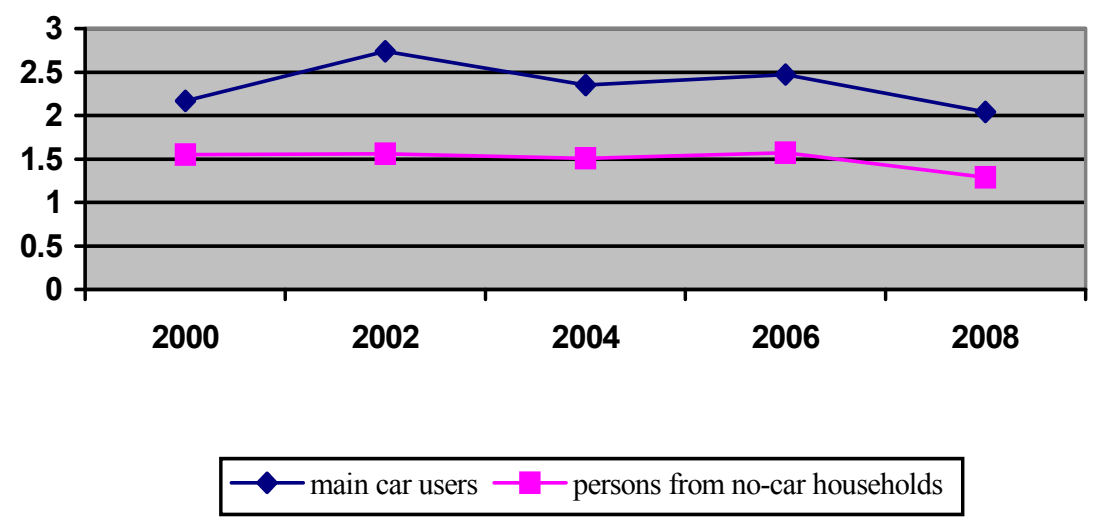

Figure 3: Urban mobility of Gdynia residents in 2000-2008 depending on the presence or absence of the car in the household.

Greater fluctuations observed in the segment of main car users are indicative of the impact of major road projects implemented by the local authority in 2000 and 2004 and the traffic disruptions involved on mobility behaviour of main car users.

\subsection{Average commuting time}

The average time spent travelling to work or school/university did not change much between 2000 and 2008 (fig. 4 and 5).

The average time spent travelling to work is 5 minutes longer by car, and 9 minutes longer by public transport. Travelling to school/university is 5 minutes longer by car, but 1 minute shorter by public transport.

The proportions between the time spent travelling to work/school/university by car versus by public transport remain basically unchanged. The feeling of respondents is that a door-to-door trip by public transport is double the time of the same trip by car.

\subsection{Reasons for choosing the car for urban trips}

The survey of mobility behaviour in Gdynia identifies the reasons for always or usually using the car for urban trips. According to the inhabitants, these are:

- shorter travelling time;

- greater comfort;

- no need to wait at public transport stops and stations;

- the car is used for one's job. 
The hierarchy of the above factors may have been changing between surveys, yet the main reasons for using the car have invariably been shorter travelling time and greater comfort.

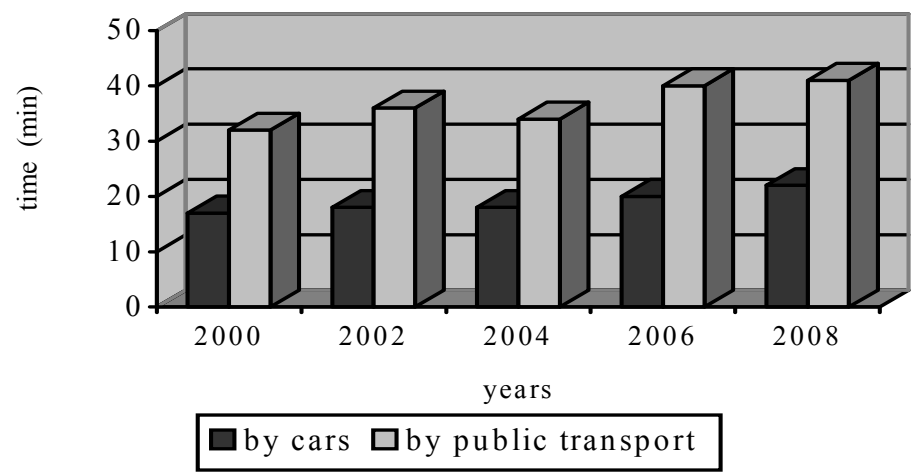

Figure 4: Average commuting time (in minutes) in Gdynia between 2000 and 2008 .

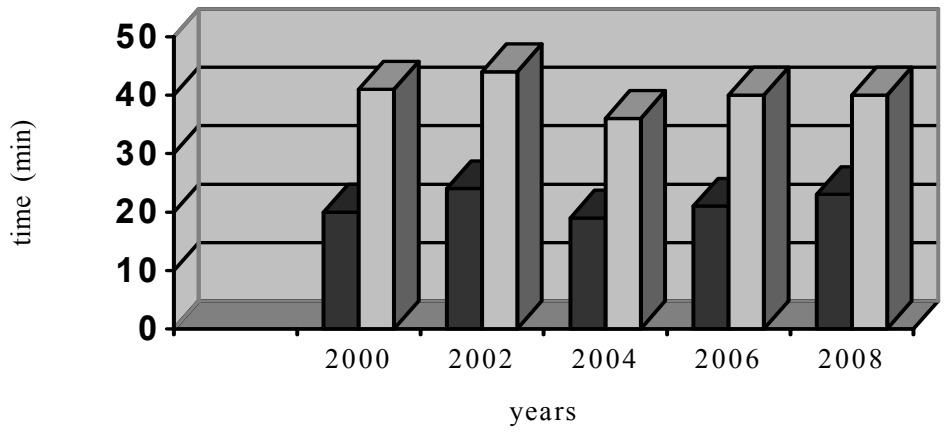

by cars $\square$ by public transport

Figure 5: Average time (in minutes) spent travelling to school/university in Gdynia between 2000 and 2008.

\subsection{Reasons for choosing public transport for urban trips}

According to the latest survey in 2008, the main reason for the use of public transport by car users is that the car is being used by someone else, followed by lower cost of a trip made by public transport, while congestion and parking difficulties rank third.

The difficulty in finding somewhere to park at the destination remains the chief reason why car users decide to use public transport (apart from the car being currently used by someone else). It has to be noted, that this was 
considered to be the most important factor, even though there were no parking fees in Gdynia at the time of the survey.

\section{Conclusions}

Mobility behaviour surveys conducted in various Polish towns and cities reveal a systematic drop in the share of urban trips made by public transport, while the role of the car is growing.

Urban mobility of the inhabitants is greater on weekdays and strongly correlates with the size of the town/city. Mobility ratio is the highest in big cities, it is smaller in other cities, and the lowest in towns.

Basic destinations are home and work/school/university. Travelling to school/university takes practically as much time as travelling to work.

The proportions between travelling to work/school/university by car versus by public transport remain stable. The feeling among the inhabitants is that a door-to-door trip by car takes only half the time it takes by public transport.

The most important reason for choosing to make urban trips by car is the shorter travelling time.

The main reason why car users travel by public transport is that someone else is using the car.

\section{References}

[1] Liberadzki B., Mindur L., (eds). Uwarunkowania rozwoju systemu transportowego Polski. (eds) Szkoła Główna Handlowa, Instytut Logistyki i Magazynowania, Instytut Technologii - Państwowy Instytut Badawczy, Warszawa-Poznań-Radom, p.164, 2006.

[2] Wyszomirski O. \&, Szałucki K. \& Grzelec K., Badania marketingowe w komunikacji miejskiej. XXVI Krajowy Zjazd Komunikacji Miejskiej. Izba Gospodarcza Komunikacji Miejskiej, Stowarzyszenie Inżynierów i Techników Komunikacji Miejskiej, Miejskie Przedsiębiorstwo Komunikacyjne Łódź Sp. z o.o., Łódź, pp.83-98, 1996

[3] Grzelec K. \& Kołodziejski H. \& Michalski L., Badania marketingowe i badania ruchu jako podstawa kształtowania oferty przewozowej w komunikacji miejskiej. XXXI Krajowy Zjazd Komunikacji Miejskiej. Kształtowanie oferty przewozowej. Izba Gospodarcza Komunikacji Miejskiej, Zarząd Komunikacji Miejskiej w Gdyni, Miejski Zakład Komunikacji Wejherowo Sp. z o.o., Zakład Komunikacji Miejskiej Sp. z o.o., Międzynarodowe Targi Gdańskie S.A., Warszawa, pp. 89-102, 2006.

[4] Hebel K., Zmiany preferencji i zachowań komunikacyjnych mieszkańców jako determinanty kształtowania oferty przewozowej i polityki transportowej w mieście w Gdyni. Transport Miejski i Regionalny 6, pp.2024, 2007.

[5] Wyszomirski O. (eds.). Transport miejski. Ekonomika i organizacja. Wydawnictwo Uniwersytetu Gdańskiego, Gdańsk, pp. 275-290, 2008. 
[6] Kompleksowe badania ruchu w Katowicach i Siemianowicach Śląskich. Synteza wyników. „Zeszyty Naukowo-Techniczne Stowarzyszenia Inżynierów i Techników Komunikacji w Krakowie, Cracow, pp.9-20, 1999.

[7] research provided by team of M. Gromadzki and O. Wyszomirski.

[8] Bryniarska Z., Nierównomierność czasowa potoków pasażerskich w publicznym transporcie w miastach. Transport Miejski i Regionalny 12, pp. 30, 2005.

[9] Grzelec K. \& Wyszomirski O., Zmiany preferencji i zachowań komunikacyjnych mieszkańców Gdyni. Porównanie wyników badań marketingowych przeprowadzonych w latach 1996,1998, 2000 i 2002. Transport Miejski 7-8, pp. 10, 2003.

[10] Starowicz W., Metoda określania przewożonych pasażerów w publicznym transporcie pasażerskim w miastach. Transport Miejski i Regionalny 12, pp. 22, 2005.

[11] Grzelec K.: Metoda określania liczby przewożonych pasażerów w publicznym transporcie zbiorowym - głos w dyskusji. Transport Miejski $i$ Regionalny, 2 pp. 35, 2006,

[12] Piechociński J. Motywacje podróży i podział zadań przewozowych. www.siskom.waw.pl/komunikacja/motywacje-podrozy.htm

[13] research provided by University of Gdańsk and Public Transport Executive in 2000, 2002, 2004, 2006 and 2008 years. 